\title{
PEMUTAKHIRAN KURIKULUM SERTIFIKASI ANKAPIN I BERDASARKAN STCW-F 1995
}

\author{
Updating ANKAPIN-I Certification Curriculum Based on STCW-F 1995 \\ Oleh: \\ Nur Atika Hasibuan ${ }^{1}$, Fis Purwangka ${ }^{1 *}$, Domu Simbolon ${ }^{1}$ \\ ${ }^{1}$ Departemen Pemanfaatan Sumberdaya Perikanan, FPIK- \\ IPB University, Indonesia \\ *Korespondensi penulis: fis@psp-ipb.org
}

\begin{abstract}
ABSTRAK
Sertifikat Ahli Nautika Kapal Penangkap Ikan tingkat 1 (ANKAPIN-I) adalah sertifikat yang wajib dimiliki oleh nakhoda dan perwira jaga navigasi sebagai bukti keterampilan dan keahlian yang dimiliki untuk bekerja di atas kapal ikan penangkapan ikan yang berukuran 24 meter atau lebih. Kurikulum sertifikasi ANKAPIN-I di Indonesia harus sesuai konvensi STCW-F 1995 dengan harapan nakhoda dan perwira jaga navigasi yang bekerja di atas kapal asing diperlakukan sesuai peraturan yang berlaku. Penelitian bertujuan (1) Menentukan kesesuaian kurikulum kompetensi STCW-F 1995 dengan kurikulum sertifikasi di Indonesia melalui jalur pendidikan, (2) Menentukan pencapaian kompetensi STCW-F 1995 di lembaga pendidikan di Indonesia. Metode penelitian dilakukan dengan studi literatur. Data yang diperoleh dianalisis menggunakan metode deskriptif komparatif dan analisis konten kuantitatif. Hasil penelitian menunjukkan bahwa kurikulum maupun elemen dalam pengambilan sertifikasi ANKAPIN-I di lembaga pendidikan Indonesia belum sesuai dengan konvensi STCW-F 1995. Untuk mempersamakan kurikulum ANKAPIN I diperlukan pemutakhiran kurikulum dan elemen terkait tata laksana keselamatan FAO/ILO/IMO untuk awak kapal ikan 24 meter ke atas, pencegahan kebakaran, alat-alat pemadam kebakaran, penyelamatan, pencarian dan pertolongan, pelayanan medis, metode untuk mendemonstrasikan keterampilan serta memberikan sanksi kepada lembaga pendidikan yang melanggar konvensi STCW-F 1995.
\end{abstract}

Kata kunci: konvensi STCW-F 1995, lembaga pendidikan, sertifikat ANKAPIN-I

\section{ABSTRACT}

ANKAPIN-I certificate is a certificate that must be owned by the captain and officer guarding the navigation as proof of skills and expertise to work on a fishing boat measuring 24 meters. The ANKAPIN-I certification curriculum in Indonesia must comply with the 1995 STCW-F convention so that captains and officers on duty for navigation on board foreign ships are treated according to applicable regulations. The research aims (1) Determine the suitability of the 1995 STCW-F competency curriculum with the certification curriculum in Indonesia through the education pathway, (2) Determine the achievement of the 1995 STCW-F competency in educational institutions in Indonesia. The research method was carried out by studying the literature. The data obtained were analyzed using comparative descriptive methods and gap analysis. The results showed that both the curriculum and elements in making ANKAPIN-I at the Indonesian Educational Institution were not in accordance with the 1995 STCW-F convention. above, fire prevention, fire extinguishing equipment, rescue, search and rescue, medical services, methods for demonstrating skills and imposing sanctions on educational institutions that violate the 1995 STCW-F convention.

Key words: ANKAPIN-I certificate, educational institutions, the 1995 STCW-F convention 


\section{PENDAHULUAN}

Menurut Peraturan Pemerintah RI Nomor 51 Tahun 2002 tentang Perkapalan, awak kapal adalah pelaut yang bekerja di atas kapal dengan bidang yang berbeda dan melakukan tugas sesuai yang tercantum dalam buku sijil. Menurut Peraturan Menteri Perhubungan nomor 30 tahun 2008, Buku sijil adalah buku yang berisi daftar awak kapal yang bekerja di atas kapal sesuai dengan jabatannya dan tanggal naik turunnya yang disahkan oleh syahbandar. Anak Buah Kapal (ABK) adalah awak kapal selain nakhoda. Nakhoda adalah perwira laut tertinggi yang bertanggung jawab di atas kapal sekaligus pemegang kendali tertinggi di atas kapal (UU RI No 17/ 2008 Pasal 1). Pelaut adalah pekerjaan yang sangat berbahaya dan memiliki risiko yang tinggi dibanding dengan pekerjaan yang ada di darat (Arleiny dan Prastyanti 2019). Pelaut menurut Peraturan Menteri Perhubungan No. 84 pasal 1 ayat 7 Tahun 2013 tentang Perekrutan dan Penempatan Awak Kapal, adalah setiap orang yang mempunyai kualifikasi keahlian dan atau keterampilan sebagai awak kapal. Seorang pelaut yang bekerja di atas kapal harus memiliki sertifikat khusus kepelautan. Menurut Peraturan Menteri Perhubungan Nomor 9 Tahun 2005 tentang Pendidikan dan Pelatihan, Ujian serta Sertifikasi Pelaut Kapal Penangkapan Ikan, pada Bab 1 Pasal 1 Sertifikat Keahlian Pelaut Kapal Penangkap Ikan adalah sertifikasi kompetensi yang merupakan pengakuan terhadap kompetensi untuk melakukan pekerjaan pelaut kapal penangkapan ikan, setelah dinyatakan lulus ujian kompetensi yang diselenggarakan oleh Dewan Penguji Keahlian Pelaut untuk semua jenjang pendidikan dan pelatihan pelaut kapal penangkap ikan. Semakin tinggi tingkat sertifikat yang dimiliki seorang pelaut, maka pengalaman yang dimiliki akan lebih banyak. Hal ini menjadi jaminan bagi keselamatan kerja dan keamanan pelayaran di atas kapal penangkap ikan.

Keselamatan dan keamanan pelayaran merupakan hal yang penting untuk diperhatikan dalam pelayaran karena ketika kapal berlayar memiliki risiko kecelakaan yang tinggi (Hasugian et al. 2017). Salah satu faktor dari kecelakaan kapal diakibatkan oleh human error seperti kesalahan ABK membaca situasi navigasi. Kesalahan ABK dalam membaca situasi navigasi disebabkan karena ilmu pengetahuan awak kapal yang kurang mampu dalam menguasai berbagai masalah dalam ilmu pelayaran, keterampilan, keahlian dan pengalaman berlayar yang kurang. Untuk menghindari kelalaian awak kapal yang menyebabkan kecelakaan maka diwajibkan bagi semua pelaut untuk memiliki sertifikat BST (Basic Safety Training). BST (Basic Safety Training) sangat penting bagi pelaut yaitu sebagai pedoman standar keselamatan saat berada di atas kapal, sertifikat BST wajib dimiliki semua awak kapal baik nakhoda, perwira dan ABK sebelum memiliki sertifikasi penunjang lainnya.

Setiap pelaut perikanan memiliki jabatan yang berbeda di atas kapal penangkap ikan, hal ini sangat tergantung kepada sertifikat yang dimilikinya di atas kapal. Setiap jabatan memiliki tingkatan sertifikasi yang berbeda. Menurut Peraturan Menteri Perhubungan Nomor 9 Tahun 2005 Pasal 15 tentang Pendidikan dan Pelatihan, Ujian serta Sertifikasi Pelaut Kapal Penangkapan ikan, jenis dan tingkatan sertifikat keahlian pelaut kapal ikan terdiri dari Sertifikat Ahli Nautika Kapal Penangkap Ikan Tingkat I (ANKAPIN-I), ANKAPIN-II, ANKAPIN-III, sertifikat Ahli Teknika Kapal Penangkap Ikan Tingkat I (ATKAPIN-I), ATKAPIN-II, ATKAPIN-III dan sertifikat Rating Kapal Penangkap Ikan. Sertifikat ANKAPIN/ATKAPIN adalah sertifikat keahlian pelaut perikanan yang dijadikan sebagai pengakuan kompetensi untuk melakukan pengoperasian penangkapan ikan yang tepat guna.

Pelaut yang memiliki tingkat sertifikasi ANKAPIN-I dikukuhkan menjadi mualim 1 untuk pelaut yang beroperasi atau bekerja di atas kapal yang panjangnya $\geq 24$ meter dan berukuran $>88$ GT dapat melakukan pelayaran di semua perairan. Pelaut yang memiliki sertifikat tingkat ANKAPIN-I dapat melakukan pelayaran di semua daerah penangkapan ikan (Budiman et al. 2016). Pemegang sertifikat ANKAPIN-II di kukuhkan menjadi Mualim I di kapal ikan ukuran 60-88 GT dengan panjang kapal 12 meter dan kurang dari 24 meter yang beroperasi pada perairan Indonesia tapi tidak termasuk ZEEI (Zona Ekonomi Eksklusif Indonesia). Sertifikat ANKAPIN II juga dapat dikukuhkan menjadi nakhoda pada kapal penangkap ikan dengan syarat memiliki pengalaman berlayar sebagai Mualim I minimal 24 bulan pada kapal penangkap ikan dan dapat dikukuhkan menjadi Mualim II pada kapal 
penangkap ikan semua ukuran kapal di perairan Indonesia di bawah 60 mil dan tidak termasuk ZEEI (Zona Ekonomi Eksklusif Indonesia), dengan syarat memiliki pengalaman berlayar minimal 12 bulan sebagai dinas jaga. Sertifikat ANKAPIN-III dapat diangkat sebagai Mualim I di atas kapal penangkap ikan ukuran 30-60 GT dengan panjang kapal di bawah 12 meter di perairan Indonesia yaitu di bawah 60 mil tidak termasuk ZEEI (Zona Ekonomi Eksklusif Indonesia). Sertifikat ANKAPIN-III juga dapat dikukuhkan sebagai nakhoda pada kapal ikan di bawah 12 meter di perairan Indonesia tidak termasuk ZEEI (Zona Ekonomi Eksklusif Indonesia) dan dikukuhkan sebagai Mualim III pada kapal berukuran 12 meter dan di bawah 24 meter di perairan Indonesia tidak termasuk ZEEI (Zona Ekonomi Eksklusif Indonesia).

Menurut Peraturan Menteri Perhubungan Nomor 70 Tahun 2013 tentang Pendidikan dan Pelatihan Sertifikasi serta Dinas Jaga Pelaut, untuk memperoleh sertifikat ANKAPIN-I terdapat dua cara yaitu: (1) melalui pelatihan dan pendidikan. Peserta pelatihan harus memenuhi persyaratan yaitu memiliki sertifikat ANKAPIN II, Pendidikan minimal SMP, mengikuti diklat selama kurang lebih 6 (enam) bulan dengan 1.200 jam pelatihan, memiliki pengalaman berlayar sebagai perwira kapal penangkap ikan sekurang-kurangnya 12 (dua belas) bulan, berusia sekurang-kurangnya 18 tahun, membayar biaya diklat sebesar Rp14.412.500,00 dan menyerahkan dokumen yang diminta, (2) melalui pendidikan dan latihan bagi yang memiliki ijazah D3 Perikanan, dengan pengalaman berlayar sekurang-kurangnya 6 bulan di kapal penangkap ikan, dan atau yang memiliki ijazah Sarjana/D3 Perikanan, dan telah dinyatakan lulus Diklat Pelaut Kapal penangkap ikan selama 12 bulan dengan pengalaman berlayar sekurang-kurangnya 12 bulan di kapal penangkap ikan.

lembaga pendidikan perikanan di seluruh Indonesia menerapkan kurikulum berdasarkan keputusan Kepala Badan Pengembangan SDM Perhubungan Nomor 7 Tahun 2016 serta peraturanperaturan yang berlaku di Indonesia tentang pengambilan sertifikasi ahli nautika kapal penangkap ikan tingkat 1. Sekolah Tinggi Perikanan Jakarta merupakan lembaga pendidikan penyelenggara sertifikasi ANKAPIN-I yang terakreditas di Jakarta. Sekolah Tinggi Perikanan Jakarta (STP) dapat mewakili lembaga pendidikan di Indonesia karena semua kurikulum pengambilan sertifikasi ANKAPIN-I mengacu kepada keputusan Kepala Badan Pengembangan SDM Kelautan dan Perikanan, selain itu, asesor/instruktur dari STP juga menguji para calon nakhoda dan perwira kapal penangkap ikan yang mengikuti sertifikasi ANKAPIN-I di kota-kota besar Indonesia seperti kota Medan, Tegal, Banyuwangi, Ambon, Sorong, Aceh, Pontianak dan kota lainnya. Bagi yang berminat mendapatkan sertifikat ANKAPIN-I langsung di Sekolah Tinggi Perikanan Jakarta yaitu melalui pendaftaran dan seleksi sebagai taruna D4 STP dan peminatannya pada jurusan Teknologi Penangkapan Ikan (TPI) yang berada di bawah asuhan program studi TPI, Lulusan dari program studi TPI akan memperoleh ijazah sarjana terapan perikanan, juga mendapatkan sertifikat BST.

Sertifikasi ahli nautika kapal penangkap ikan tingkat 1 di Indonesia saat ini masih bermasalah karena kurikulum sertifikasi belum sesuai dengan Standards of Training, Certification and Watchkeeping for Fishing Vessel Personnel (STCW-F 1995). Dampaknya adalah belum diakui oleh negara-negara lain menyebabkan para awak kapal Indonesia yang telah memiliki sertifikat dan bekerja di atas kapal asing tidak dapat menduduki jabatan sebagai nakhoda atau perwira kapal di atas kapal penangkap ikan negara luar. Peristiwa yang lebih menyedihkan adalah sebagian besar para anak buah kapal diperlakukan dengan tidak wajar. Contoh peristiwa seperti yang terjadi pada sebuah kapal ikan penangkap tuna dari Cina yaitu kapal ikan Long Xing 629, anak buah kapal dari Indonesia yang bekerja di atas kapal ikan tersebut meninggal dunia akibat dari kekerasan fisik dari kru kapal senior. Lebih tragis Jenazahnya dibuang ke laut (Samudera Pasifik), pembuangan jenazah awak kapal di laut tidak sesuai dengan kontrak kerja yang disepakati, kontrak kerja yang disepakati antara kedua belah pihak adalah apabila terjadi musibah dan meninggal dunia maka jenazah akan dikremasikan di tempat di mana kapal menyandar dengan catatan abu jenazah dipulangkan ke Indonesia (Samudra 2020). Masalah yang sering dihadapi oleh ABK WNI adalah kasus perbudakan di atas kapal, tentang penerimaan gaji 
yang tidak sesuai dengan kontrak kerja dan diskriminasi upah dengan pelaut warga negara asing (Adela 2018).

Menurut Direktur Eksekutif Pekerja Migran, Susilo (2020) menyatakan bahwa salah satu penyebab kasus perbudakan pada awak kapal Indonesia adalah ketidaksiapan pemerintah Indonesia dalam menyiapkan sumberdaya manusia dalam sektor kemaritiman. Hal ini kurangnya perhatian pemerintah terhadap pendidikan dan pelatihan untuk calon awak kapal perikanan. Berdasarkan uraian di atas, sertifikat pelaut perikanan WNI yang bekerja di kapal asing tidak diakui di kalangan internasional oleh karenanya, peneliti berkeinginan untuk meneliti kesenjangan antara materi kurikulum sertifikasi awak kapal pada jenjang ANKAPIN-I melalui jalur pendidikan dengan materi kurikulum STCW-F 1995 yang telah diratifikasi di Indonesia. STCW-F 1995 hanya mengatur kapal yang panjangnya $\geq 24$ meter. Oleh karenanya peneliti mengarahkan kajiannya pada jenjang sertifikasi ANKAPIN I.

Dampak dari Sertifikasi ANKAPIN-I melalui jenjang pendidikan di Indonesia tidak diakui secara internasional, menyebabkan ABK yang bekerja di kapal ikan berbendera asing dipekerjakan hanya sebagai ABK biasa yang jabatannya hanya sebagai ABK biasa dipersamakan dengan ABK yang tanpa memiliki sertifikat seperti Seaman madya (AB) dan Seaman biasa (kelasi), dampak lainnya adalah terhadap gaji yang diterima tidak sesuai dengan standar internasional. Penelitian ini bertujuan untuk menentukan kesesuaian kurikulum kompetensi STCW-F 1995 dengan kurikulum sertifikasi di Indonesia melalui jenjang Pendidikan, dan menentukan pencapaian kompetensi STCW-F 1995 di lembaga pendidikan di Indonesia.

\section{METODE PENELITIAN}

Penelitian dilaksanakan pada bulan Maret-Juli 2020 dengan melakukan studi literatur menggunakan data kurikulum STCW-F 1995 dilaksanakan di Fakultas Perikanan dan Ilmu Kelautan Institut Pertanian Bogor dan pengambilan data kurikulum ANKAPIN-I di salah satu lembaga pendidikan penyelenggara sertifikasi di Indonesia yaitu Sekolah Tinggi Perikanan Jakarta.

Metode yang dilakukan dalam penelitian adalah dengan melakukan studi literatur. Studi literatur adalah proses umum yang dilakukan untuk mencari teori terkait standar kurikulum di lembaga pendidikan Indonesia dan standar kurikulum Internasional, lalu disusun secara teratur dan rapi untuk dipergunakan dalam keperluan penelitian (Sevilla 1993). Pendekatan yang digunakan adalah pendekatan analisis konten kuantitatif dan pendekatan deskriptif komparatif. Deskriptif komparatif yaitu membandingkan satu variabel atau lebih sehingga dapat menemukan persamaan-persamaan maupun perbedaan antara variabel yang diteliti (Aji 2017). Penggunaan metode deskriptif komparatif dalam penelitian ini adalah dengan membandingkan kedua kurikulum ANKAPIN-I yaitu data Peraturan Presiden Nomor 18 Tahun 2019 tentang Ratifikasi STCW-F 1995 yang dapat diunduh di Internet dan kurikulum sertifikasi ANKAPIN-I diperoleh dari Sekolah Tinggi Perikanan Jakarta (STP). STP merupakan salah satu sekolah di bawah pengelolaan kementerian kelautan dan perikanan. Kedua data tersebut dapat mewakili kurikulum sertifikasi ANKAPIN-I versi internasional dan versi Indonesia. Konvensi STCW-F 1995 adalah peraturan yang sah yang diadopsi oleh International Maritime Organization pada konverensi internasional pada tanggal 26 Juni sampai 7 Juli 1995 dan kurikulum ANKAPIN-I yang berlaku di lembaga pendidikan Indonesia adalah keputusan dari Kepala Badan Pengembangan Sumber Daya Manusia yang merupakan unit kerja dari kementerian kelautan dan perikanan.

Analisis konten kuantitatif adalah analisis karekteristik pesan yang sistematis dan objektif (Neuendorf 2002). Penelitian ini menggunakan analisis konten kuantitatif untuk mengetahui pencapaian kurikulum yang berlaku dengan kurikulum standar internasional. Metode analisis konten 
kuantitatif untuk menjawab pemutahiran kurikulum untuk masa yang akan datang. Data yang dianalisis yaitu dokumen Peraturan Presiden Nomor 18 Tahun 2019 tentang Ratifikasi STCW-F 1995 (sebagai standar acuan) dan standar kurikulum pendidikan sertifikasi ANKAPIN-I di lembaga pendidikan secara teori. Selanjutnya menghitung tingkat implementasi kurikulum yang terdapat pada lembaga pendidikan berdasarkan konvensi STCW-F 1995. Cara menghitung persentasi tersebut dengan menggunakan rumus tingkat kesesuaian yaiu menjumlahkan kurikulum yang telah diterapkan di lembaga pendidikan, lalu dibagi dengan jumlah kurikulum standar internasional kemudian dikali seratus persen. Jika kurikulum diterapkan sesuai dengan konvensi STCW-F1995 maka nilainya 1 dan jika tidak diterapkan nilainya nol. Menghitung nilai persentase kurikulum yang tidak sesuai antara keduanya yaitu seratus dikurangi dengan hasil persentase dari implementasi pada lembaga pendidikan. Perhitungan nilai implementasi dapat dirumuskan yaitu:

Kesesuaian $=\left(\sum \mathrm{a} / \sum \mathrm{b}\right) \times 100 \%$

Keterangan:

$\sum \mathrm{a}=$ Jumlah materi kurikulum yang diterapkan lembaga pendidikan

$\sum \mathrm{b}=$ Jumlah materi kurikulum yang berlaku pada ratifikasi STCW-F 1995

Kesesuaian $=$ Tingkat kesesuaian kurikulum

Analisis deskriptif komparatif adalah metode untuk menjawab tujuan nomor dua yaitu dengan mengumpulkan data yang akan diteliti yaitu elemen-elemen hasil dari analisis kurikulum lembaga pendidikan di Indonesia dan Peraturan Presiden Nomor 18 Tahun 2019 tentang Ratifikasi STCW-F 1995 (sebagai standar acuan), kemudian membandingkan elemen-elemen dari kedua kurikulum tersebut, selanjutnya dapat persamaan dan perbedaan dari kedua variabel. Kemudian menghitung tingkat implementasi elemen yang terdapat pada kedua kurikulum, jika elemen pada kurikulum pendidikan Indonesia sesuai dengan konvensi STCW-F 1995 maka nilainya satu jika tidak sesuai nilainya nol. Cara menghitung persentase tersebut yaitu dengan menggunakan rumus tingkat kesesuaian yaitu sama dengan tujuan nomor satu dengan cara menjumlahkan elemen yang telah diterapkan di lembaga pendidikan, lalu dibagi dengan jumlah elemen standar internasional kemudian dikali seratus persen.

\section{HASIL DAN PEMBAHASAN}

\section{Kesesuaian Kurikulum Kompetesi STCW-F 1995 Dengan Kurikulum Sertifikasi di Indonesia Melalui Jalur Pendidikan}

Nakhoda dan perwira yang bekerja di atas kapal penangkap ikan dengan panjang 24 meter atau lebih wajib memiliki sertifikat yang berlaku secara internasional. Sertifikat pada kapal penangkap ikan berbeda dengan sertifikat kapal niaga, di mana kapal penangkap ikan mengacu pada STCW-F 1995 disebut sebagai ANKAPIN dan ATKAPIN. Sertifikat pelaut kapal penangkap ikan terbagi menjadi tiga tingkat yaitu ANKAPIN tingkat I, ANKAPIN tingkat II dan ANKAPIN tingkat III. Pelaut yang bekerja di atas dek kapal perikanan yang panjangnya di atas 24 meter atau lebih harus memiliki sertifikat tingkat ANKAPIN-I. Pengambilan sertifikat ANKAPIN-I di Indonesia ada dua cara yaitu dengan pelatihan dan melalui pendidikan.

Syarat keikutsertaan dalam sertifikasi ANKAPIN-I seorang pelaut harus memiliki sertifikat keterampilan keselamatan dasar yang disebut dengan BST. Sedangkan untuk mendapatkan sertifikat BST, peserta harus mengikuti pelatihan selama 8(delapan) sampai 10 (sepuluh) hari dengan kurikulum yang telah ditetapkan. Kegiatan pelatihan BST dimulai dengan tes kesehatan berupa tekanan darah, tes buta warna, riwayat penyakit serta pemeriksaan umum lainnya. Usia minimal pengambilan sertifikat BST 18 tahun dan usia maksimal 50 tahun dengan biaya berkisar antara Rp1.250.000,00 sampai Rp1.500.000,00. Masa berlaku sertifikat BST yaitu lima tahun dan bisa diperpanjang dengan revalidasi. 
Fasilitas dasar yang dibutuhkan adalah kolam renang, kelas indoor dan outdoor, tempat ibadah, penginapan, kantin dan fasilitas umum lainnya (Prayogo 2020). Pelaksanaan BST ini sesuai dengan syarat sertifikasi untuk semua jenjang sertifikat kompetensi pelaut. Materi dalam kurikulum standar BST yang ditetapkan oleh Indonesia maupun STCW-F 1995 disajikan pada pada Tabel 1.

Tabel 1. Materi BST di Indonesia dan STCW-F 1995

\begin{tabular}{lll}
\hline No. & \multicolumn{1}{c}{ Kurikulum di Indonesia } & \multicolumn{1}{c}{ Kurikulum STCW-F } \\
\hline I. & $\begin{array}{l}\text { Pengenalan keselamatan dan bertahan } \\
\text { hidup }\end{array}$ & $\begin{array}{l}\text { Kemampuan bertahan hidup (pakai } \\
\text { pelampung, mengenakan pakaian sesuai }\end{array}$ \\
& $\begin{array}{l}\text { 1. POP) } \\
\text { 2. Prinsip bertahan hidup di laut }\end{array}$ & \\
\hline II. $\quad \begin{array}{l}\text { Keadaan darurat } \\
\text { 1. } \quad \begin{array}{l}\text { Faktor-faktor penyebab keadaan } \\
\text { darurat }\end{array}\end{array}$ & Prosedur darurat \\
& 2. Persiapan keadaan darurat \\
& 3. Penyediaan peralatan pemadam \\
& $\quad$ kebakaran & \\
\hline III. & Isyarat bahaya & \\
\hline IV. & Evakuasi & Pencegahan kecelakaan kapal \\
\hline V. & Sudah ada & Pencegahan pencemaran laut. \\
& & $\begin{array}{l}\text { Pencegahan kebakaran dan pemadam } \\
\text { kebakaran serta pertolongan pertama } \\
\text { (tindakan-tindakan dasar) }\end{array}$ \\
\hline
\end{tabular}

Menurut Peraturan Presiden Republik Indonesia Nomor 18 tahun 2019 Tentang Pengesahan International Convention on Standards of Training, Certification and Watchkeeping for Fishing Vessel Personnel 1995, dalam hal meningkatkan keselamatan jiwa, harta benda di laut serta perlindungan lingkungan laut melalui kesepakatan bersama untuk menetapkan standar internasional pelatihan, sertifikasi dan tugas jaga bagi orang yang bertugas di atas kapal penangkap ikan, semua lembaga pendidikan di Indonesia terkait pengambilan sertifikasi keahlian ANKAPIN-I wajib memberlakukan peraturan tersebut. Adapun konsekuensi yang diterima oleh Indonesia terkait pengesahan STCW-F 1995 yaitu 1). Aspek hukum, perlu mengharmonisasikan atau menselaraskan semua peraturan yang mengatur terkait sertifikasi kepelautan, pengawakan kapal perikanan, ketenagakerjaan yang berkaitan dengan kapal perikanan, keselamatan pelayaran kapal perikanan, keselamatan dalam penangkapan ikan pada kapal ikan, daerah pelayaran kapal perikanan dan pendidikan serta pelatihan awak kapal perikanan. 2). Aspek kelembagaan, Indonesia harus menetapkan lembaga yang bertanggung jawab atas pemberlakuan STCW-F 1995, untuk mengemban tugas ini adalah Badan Pengembangan SDM Kelautan dan Perikanan. Sejauh ini lembaga Pengembangan SDM Kelautan dan Perikanan sudah menyelenggarakan pendidikan dan pelatihan dibidang kelautan dan perikanan akan tetapi belum sepenuhnya mengikuti standar konvensi STCW-F 1995. 3). Aspek pendidikan dan pelatihan, ujian serta sertifikasi kepelautan perikanan, Indonesia harus memenuhi standar kurikulum, tenaga pengajar, sarana dan prasarana, ujian dan sertifikasi, pengelolaan pendidikan dan pelatihan kepelautan perikanan serta lembaga penyelenggara ujian harus sesuai dengan konvensi STCW-F 1995. 4). Aspek ekonomi, Indonesia harus membayar iuran wajib dan sukarela sebagai anggota kelembagaan konvensi STCW-F 1995 sesuai dengan ketentuan yang berlaku. Selain dari konsekuensi tersebut pengesahan STCW-F 1995 memiliki keuntungan bagi Indonesia.

Keuntungan bagi Indonesia yaitu 1). Meningkatkan kerjasama internasional khususnya di bidang kelautan dan perikanan, adanya perlakuan yang adil dan tidak diskriminatif terhadap awak kapal perikanan Indonesia, dengan meningkatnya standar kualitas awak kapal perikanan Indonesia dunia internasional akan memposisikan awak kapal perikanan Indonesia sejajar dengan awak kapal 
perikanan negara lain yang lebih maju, meningkatkan investasi usaha di bidang kelautan dan perikanan di dalam negeri dan lain sebagainya. Adapun negara yang sudah meratifikasi konvensi STCW-F 1995 sebanyak 74 negara yaitu beberapa diantaranya Australia, Argentina, Belgia, Brazil, Kanada, China, Perancis, Jerman, Arab Saudi, Jepang, Turki, Belanda dan lainnya. Selain konsekuensi dan keuntungan yang diterima oleh Indonesia namun pemerintah RI wajib menjalankan konvensi STCW-F 1995.

Kewajiban Indonesia dalam menjalankan konvensi STCW-F 1995 yaitu melaporkan kebijakan yang telah diambil dalam memberlakukan sepenuhnya ketentuan-ketentuan konvensi STCW-F 1995, termasuk contoh sertifikat yang diterbitkan oleh pemerintah RI sesuai dengan konvensi STCW-F 1995 kepada sekjen IMO. 2). yaitu memberlakukan mensosialisasikan ketentuan-ketentuan konvensi STCW-F 1995 dan seluruh lampirannya. 3). yaitu pengelolaan pendidikan dan pelatihan harus sesuai dengan yang dipersyaratkan dalam konvensi STCW-F 1995 yaitu memenuhi standar kurikulum, tenaga pengajar, sarana dan prasarana serta ujian dan sertifikasi. 4). yaitu meninjau kembali kesepakatan, perjanjian, dan konvensi untuk menjamin bahwa tidak ada pertentangan dengan konvensi STCW-F 1995. 5). adalah melakukan kerjasama dengan negara lain yang telah mengesahkan konvensi STCW-F 1995. 6). Hal-hal yang tidak tegas diatur dalam konvensi STCW-F 1995 tetap harus tunduk kepada perundang-undangan yang berlaku di Indonesia. Setelah melakukan pertimbangan dalam proses pengesahan konvensi STCW-F 1995 baik dari segi konsekuensi, keuntungan dan kewajiban yang akan diterima oleh Indonesia maka perjanjian internasional tentang konvensi STCW-F 1995 akan diberlakukan di Indonesia.

Menurut Undang-Undang RI Nomor 24 Tahun 2000 Tentang Perjanjian Internasional, proses pengesahan perjanjian internasional oleh pemerintah RI dilakukan dengan undang-undang atau keputusan presiden. Proses pengesahan ratifikasi STCW-F 1995 dilakukan dengan keputusan presiden, setiap keputusan presiden yang mengesahkan suatu perjanjian internasional diserahkan kepada dewan perwakilan rakyat dievaluasi selanjutnya KKP dan lembaga negara terkait menyiapkan salinan naskah perjanjian (konvensi STCW-F 1995) serta dokumen-dokumen yang diperlukan. Kementerian Kelautan dan Perikanan yang terdiri dari lembaga negara dan lembaga pemerintah mengkoordinasikan pembahasan rancangan (konvensi STCW-F 1995) yang pelaksanaannya dilakukan bersama dengan pihak-pihak terkait. Prosedur pengajuan (konvensi STCW-F 1995) dilakukan melalui menteri untuk disampaikan kepada presiden. Keputusan presiden tentang konvensi STCW-F 1995 ditempatkan dalam lembaran negara republik Indonesia kemudian menteri menandatangani piagam pengesahan untuk mengikatkan pemerintah republik Indonesia untuk dipertukarkan dengan pihak negara atau disimpan oleh negara atau lembaga penyimpan pada organisasi internasional. Perjanjian yang telah diratifikasi oleh Indonesia tentang konvensi STCW-F 1995 memiliki kesesuaian dan perbedaan dengan kurikulum di lembaga pendidikan Indonesia. Adapun kesesuaian dan perbedaan kurikulum yang diatur dalam konvensi STCW-F 1995 dengan kurikulum ANKAPIN-I di lembaga pendidikan Indonesia dapat dilihat pada Tabel 2.

Tabel 2. Kurikulum pendidikan di Indonesia dan Kurikulum STCW-F 1995.

\begin{tabular}{|c|c|c|c|c|c|}
\hline \multirow[b]{2}{*}{ No. } & \multirow[b]{2}{*}{ Kurikulum STCW-F 1995} & \multirow[b]{2}{*}{ No } & \multirow{2}{*}{$\begin{array}{l}\text { Kurikulum Sekolah Tinggi } \\
\text { Perikanan Jakarta }\end{array}$} & \multicolumn{2}{|c|}{ Keterangan } \\
\hline & & & & Ada & $\begin{array}{c}\text { Tidak } \\
\text { ada }\end{array}$ \\
\hline 1. & $\begin{array}{l}\text { Navigasi/perencanaan } \\
\text { pelayaran }\end{array}$ & 1. & Perencanaan pelayaran & $\checkmark$ & \\
\hline 2. & Penentuan posisi & 2. & Pelayaran astronomi & $\checkmark$ & \\
\hline 3. & Pelayaran datar & 3. & Pelayaran datar & $\checkmark$ & \\
\hline 4. & Dinas jaga & 4. & Dinas jaga/P2TL & $\checkmark$ & \\
\hline 5. & Navigasi radar & 5. & $\begin{array}{l}\text { Navigasi radar dan navigasi } \\
\text { elektronik }\end{array}$ & $\checkmark$ & \\
\hline
\end{tabular}




\begin{tabular}{|c|c|c|c|c|c|}
\hline \multirow[b]{2}{*}{ No. } & \multirow[b]{2}{*}{ Kurikulum STCW-F 1995} & \multirow[b]{2}{*}{ No } & \multirow[b]{2}{*}{$\begin{array}{l}\text { Kurikulum Sekolah Tinggi } \\
\text { Perikanan Jakarta }\end{array}$} & \multicolumn{2}{|c|}{ Keterangan } \\
\hline & & & & Ada & $\begin{array}{c}\text { Tidak } \\
\text { ada }\end{array}$ \\
\hline 6. & $\begin{array}{l}\text { Kompas magnet dan kompas } \\
\text { gasing }\end{array}$ & 6. & $\begin{array}{l}\text { Kompas magnet dan kompas } \\
\text { gasing }\end{array}$ & $\checkmark$ & \\
\hline 7. & Meteorologi dan oseanografi & 7. & Meteorologi dan oseanografi & $\checkmark$ & \\
\hline 8. & $\begin{array}{l}\text { Bangunan dan stabilitas kapal } \\
\text { penangkap ikan }\end{array}$ & 8. & $\begin{array}{l}\text { Bangunan dan stabilitas kapal } \\
\text { penangkapan ikan }\end{array}$ & $\checkmark$ & \\
\hline 9. & $\begin{array}{l}\text { Penanganan dan } \\
\text { penyimpanan hasil } \\
\text { tangkapan }\end{array}$ & 9. & $\begin{array}{l}\text { Penanganan dan penyimpananan } \\
\text { hasil tangkapan }\end{array}$ & $\checkmark$ & \\
\hline 10. & $\begin{array}{l}\text { Olah gerak dan penanganan } \\
\text { kapal penangkap ikan }\end{array}$ & 10. & $\begin{array}{l}\text { Olah gerak dan pengendalian } \\
\text { kapal penangkapan ikan }\end{array}$ & $\checkmark$ & \\
\hline 11. & Hukum maritim & 11. & $\begin{array}{l}\text { Hukum maritim dan peraturan } \\
\text { perikanan }\end{array}$ & $\checkmark$ & \\
\hline 12. & Prosedur darurat & 12. & Prosedur darurat & $\checkmark$ & \\
\hline 13. & Pelayanan medis & & - & & $\checkmark$ \\
\hline 14. & Bahasa inggris & 13. & $\begin{array}{l}\text { Bahasa inggris maritim dan } \\
\text { perikanan }\end{array}$ & $\checkmark$ & \\
\hline \multirow[t]{2}{*}{15.} & $\begin{array}{l}\text { Pencegahan kebakaran dan } \\
\text { alat-alat pemadam kebakaran }\end{array}$ & & - & & $\checkmark$ \\
\hline & & 14. & Manajemen kapal penangkap ikan & & \\
\hline 16. & Komunikasi & 15. & Komunikasi & $\checkmark$ & \\
\hline \multirow[t]{2}{*}{17.} & Penyelamatan & & - & & $\checkmark$ \\
\hline & & 16. & $\begin{array}{l}\text { Daerah, metoda dan teknik } \\
\text { penangkapan }\end{array}$ & & \\
\hline 18. & Pencarian dan pertolongan & & - & & $\checkmark$ \\
\hline \multirow[t]{2}{*}{19.} & $\begin{array}{l}\text { Tata laksana keselamatan } \\
\text { FAO/ILO/IMO untuk } \\
\text { nelayan dan kapal } \\
\text { penangkapan ikan }\end{array}$ & & - & & $\checkmark$ \\
\hline & & 17. & $\begin{array}{l}\text { Penanganan ikan yang } \\
\text { bertanggung jawab (CCRF) }\end{array}$ & & $\checkmark$ \\
\hline 20. & $\begin{array}{l}\text { Metode untuk } \\
\text { mendemonstrasikan } \\
\text { keterampilan }\end{array}$ & 18. & Praktik laut & $\checkmark$ & \\
\hline \multirow[t]{2}{*}{21.} & $\begin{array}{l}\text { Tenaga penggerak kapal } \\
\text { penangkap ikan }\end{array}$ & 19. & Permesinan kapal penangkap ikan & $\checkmark$ & \\
\hline & & 20. & Bahan dan alat tangkap & & \\
\hline Total & 21 & & 20 & 16 & \\
\hline
\end{tabular}

Kurikulum perencanaan pelayaran di lembaga pendidikan bagi pemegang ANKAPIN-II menuju ANKAPIN-I yaitu 30 jam teori dan 36 jam praktik, di mana satu jam terdiri dari 45 menit. Proses penyampaian materi dilakukan dengan belajar di kelas secara tertulis, secara lisan, dilengkapi dengan penugasan dan praktik atau simulasi di lapangan. Materi pelayaran astronomi adalah materi yang mencakup tentang pengoperasian sekstan, daftar almanak nautika dan daftar ilmu pelayaran. Materi pelayaran astronomi terdiri dari 40 jam teori dan 40 jam praktik. Metode pembelajarannya yaitu di belajar di kelas dan di evaluasi secara lisan, tertulis, penugasan dan praktik. 
Kurikulum pelayaran datar di lembaga pendidikan Indonesia terdiri dari 18 jam teori dan 30 jam praktik. Kompetensi pelayaran datar berguna untuk menentukan posisi dan bernavigasi dengan dengan bantuan benda darat/bumi pada pelayaran tak terbatas. Materi ini disampaikan dengan proses belajar mengajar di ruang kelas dan melakukan praktik di lapangan. Materi navigasi radar dan elektronik terdiri dari 24 jam teori dan 40 jam praktik. Materi navigasi radar dan elektronik berguna untuk melaksanakan tugas jaga dengan radar dan navigasi elektronik pada pelayaran tak terbatas. Penyampaian materi dilakukan di dalam kelas dan melakukan praktik di lapangan.

Materi dinas jaga dan P2TL terdiri dari 24 jam teori dan 40 jam praktik. Dinas jaga berguna untuk melaksanakan dinas jaga laut dalam operasi penangkapan ikan. Metode pembelajaran yang digunakan adalah belajar di kelas dilengkapi dengan penugasan dan melakukan praktik atau simulasi. Kurikulum meteorologi dan oseanografi adalah materi untuk pemahaman, penerapan pengetahuan dan keterampilan dalam kondisi cuaca serta oseanografi pada saat operasi penangkapan ikan baik di perairan pantai maupun perairan lepas pantai. Materi meteorologi dan oseanografi terdiri dari 18 jam teori dan tidak ada praktik di lapangan. Metode pembelajaran yaitu belajar di dalam kelas dengan tertulis, lisan, penugasan praktik atau simulasi dalam ruangan.

Materi kompas magnet dan kompas gasing adalah materi untuk menggunakan kompas magnet dan kompas gasing. Materi kompas magnet dan kompas gasing terdiri dari 20 jam teori dan 30 jam praktik. Metode pembelajaran dilakukan secara tertulis, lisan dan penugasan di dalam kelas dan praktik atau simulasi di lapangan. Kurikulum komunikasi yaitu berguna untuk melaksanakan tugas jaga dalam komunikasi antar stasiun radio pantai dengan stasiun bergerak atau sebaliknya dan antar stasiun bergerak yang satu dengan stasiun bergerak lainnya, secara efektif dan efisien. Materi komunikasi terdiri dari 18 jam teori dan 40 jam praktik. Metode pembelajaran yang digunakan adalah secara tertulis, lisan, penugasan dan praktik di lapangan. Kurikulum olah gerak dan penanganan kapal penangkap ikan yaitu mengolah gerak dan mengendalikan kapal penangkap ikan di perairan tak terbatas. Materi olah gerak dan penanganan kapal penangkap ikan terdiri dari 20 jam teori dan 30 jam praktik. Sistem belajar mengajar yang dilakukan adalah teori disampaikan di ruang kelas dan melakukan praktik di lapangan.

Kurikulum tentang bangunan dan stabilitas kapal penangkap ikan berguna untuk mengetahui secara umum struktur utama dan bagian-bagian serta ukuran kapal dan mampu melakukan perhitungan stabilitas awal dan gaya-gaya apa yang mempengaruhi stabilitas dalam operasi penangkapan. Materi bangunan dan stabilitas kapal penangkap ikan terdiri dari 24 jam teori dan 40 jam praktik. Sistem belajar mengajar dilakukan di dalam kelas dan praktik di lapangan. Materi permesinan kapal penangkap ikan terdiri dari 18 jam teori dan 30 jam praktik. Materi permesinan kapal penangkap ikan berguna untuk mengetahui dan memahami prinsip kerja mesin-mesin di kapal ikan. Metode pembelajaran yang dilakukan adalah belajar di kelas secara tertulis, lisan, dilengkapi dengan penugasan dan melakukan simulasi atau praktik.

Kurikulum tentang hukum maritim dan peraturan perikanan terdiri dari 18 jam teori. Hukum maritim dan peraturan perikanan berguna untuk mengetahui dan menerapkan peraturan perundangundangan tentang pelayaran dan perikanan yang terkait dengan keamanan dan keberhasilan pelayaran dan usaha perikanan di laut. Metode pembelajaran dilakukan di dalam kelas secara tertulis, lisan dan dilengkapi dengan penugasan. Materi tentang bahasa inggris dan perikanan berguna untuk pemahaman dan kemampuan menerapkan komunikasi sesuai dengan Standard Marine Communication Phrases (SMCP) dan interpretasi terbitan nautika dan peta dalam bahasa Inggris sesuai dengan daerah penangkapan. Materi bahasa inggris maritim terdiri dari 18 jam teori dan 30 jam praktik. Metode pembelajaran yang dilakukan secara tertulis, lisan dilengkapi dengan penugasan dan melakukan praktik di lapangan.

Kurikulum manajemen kapal penangkap ikan terdiri dari 20 jam teori. Materi manajemen kapal penangkapan ikan berguna untuk menerapkan sistem manajemen yang baik dalam angka keberhasilan 
suatu usaha penangkapan ikan di laut. Pembelajaran dilakukan di ruang kelas secara tertulis, lisan dan praktik. Materi daerah, metode dan teknik penangkapan terdiri dari 28 jam teori dan 40 jam praktik. Materi ini berguna untuk penguasaan/pemahaman daerah, metode dan dapat menetapkan metode dan teknik alat tangkap ikan yang digunakan (rawai, pukat hela, pukat cincin, jaring insang). metode pembelajaran dilakukan dengan tertulis, lisan, penugasan dan praktik atau simulasi.

Materi penanganan dan penyimpanan hasil tangkapan terdiri dari 16 jam teori dan 30 jam praktik. Materi penanganan dan penyimpanan hasil tangkapan berguna untuk melakukan penanganan ikan di kapal, mendinginkan dan membekukan ikan sesuai dengan standar mutu internasional. Sistem pembelajaran dilakukan dengan tertulis, lisan, penugasan dan simulasi atau praktik. Kurikulum tentang prosedur darurat berguna untuk mencegah suatu kondisi yang tidak diinginkan. Materi prosedur darurat terdiri dari 16 jam teori dan 30 jam praktik. Pembelajaran dilakukan di kelas dan di lapangan dengan cara tertulis, lisan, penugasan dan praktik. Akhir pembelajaran dilakukan praktik laut yang berguna untuk menajamkan kompetensi dalam operasi penangkapan ikan dan keselamatan pelayaran untuk mencapai keberhasilan usaha penangkapan ikan. Praktik laut mempunyai 128 jam di mana kenavigasian terdiri dari $40 \mathrm{jam}$, pengoperasiaan dan pengendalian kapal 40 jam dan yang terakhir operasi penangkapan ikan 48 jam. Praktik laut dilaksanakan pada akhir pelaksanaan diklat.

Tabel 2 menunjukkan bahwa kurikulum STCW-F 1995 memiliki beberapa kesamaan dengan kurikulum Sekolah Tinggi Perikanan Jakarta. Sekolah Tinggi Perikanan Jakarta telah dapat mengakomodir kurikulum STCW-F 1995 terkait dengan hal-hal berikut: navigasi atau perencanaan pelayaran, penentuan posisi atau pelayaran astronomi, dinas jaga, pelayaran datar, kompas magnet dan kompas gasing, navigasi radar, meteorologi dan oseanografi, bangunan dan stabilitas kapal penangkap ikan, penanganan dan penyimpanan hasil tangkapan, olah gerak dan penanganan kapal penangkap ikan, hukum maritim, prosedur darurat, bahasa inggris, komunikasi, tenaga penggerak kapal penangkap ikan dan praktik laut atau metode mendemonstrasikan keterampilan. Materi kurikulum tersebut di atas merupakan suatu bekal yang sangat penting untuk meningkatkan wawasan atau kemampuan seorang nakhoda/perwira kapal penangkap ikan. Untuk menjadi nakhoda dan perwira yang kompeten harus memiliki pengetahuan yang luas dan memiliki keterampilan yang kompeten (Setiawati et al. 2019). Pengetahuan minimum dan kemampuan yang harus dimiliki seorang nakhoda dan perwira sudah diatur di Peraturan Presiden Nomor 18 Tahun 2019 tentang Ratifikasi STCW-F 1995.

Pelaut Indonesia yang bekerja di kapal penangkap ikan berbendera asing harus mampu bersaing dikancah internasional baik dari segi pendidikan, keterampilan dan pengalaman yang setara dengan pelaut negara asing (Lukman 2016). Nakhoda dan anak buah kapal yang bekerja di atas kapal penangkap ikan $\geq 24$ meter harus menguasai semua kompetensi yang sudah ditetapkan pada STCW-F 1995. Menurut data kapal-kapal yang berukuran panjang kurang dari 24 meter juga banyak yang berlayar di laut lepas melakukan operasi penangkapan ikan, sehingga peluang potensi kecelakaan lebih tinggi dibanding ABK kapal berukuran $\geq 24$ meter hal ini disebabkan karena tidak sesuai dengan standar yang ditetapkan. Berdasarkan titik acuan standar kurikulum STCW-F 1995 ada beberapa materi yang belum tercantum atau belum diadopsi pada pengambilan sertifikasi ANKAPIN-I di Indonesia yaitu pelayanan medis, pencegahan kebakaran dan pemadam kebakaran, pencarian dan pertolongan, penyelamatan, tata laksana keselamatan FAO/ILO/IMO untuk nelayan dan kapal penangkap ikan. Kelima materi kurikulum tersebut penting untuk dikuasai oleh nakhoda dan perwira agar menjadi pelaut yang kompeten dan setara dengan pelaut asing.

Pelayanan medis adalah salah satu kompetensi yang wajib dikuasai oleh seorang nakhoda dan perwira pemegang sertifikat ANKAPIN-I. Hal ini berhubungan dengan keselamatan dan pertolongan di atas kapal. Pelaut yang bekerja di atas kapal memiliki banyak risiko bahaya maka, nakhoda dan perwira harus mengetahui tentang prosedur pertolongan pertama pada kecelakaan dan pengetahuan prosedur untuk memperoleh petunjuk medis melalui radio (STCW-F 1995). 
Pencegahan kebakaran dan alat-alat pemadam kebakaran merupakan kompetensi yang harus dipahami oleh nakhoda dan perwira jaga navigasi yaitu seperti pengorganisasian latihan pemadam kebakaran, bahan kimia dan kelas-kelas kebakaran dan sistem pemadam kebakaran. Pengetahuan tentang pencegahan kebakaran dapat meminimalisir risiko bahaya bahkan dapat mencegah terjadinya kapal meledak atau kebakaran pada kapal penangkapan ikan. Pengetahuan tentang alat-alat pemadam kebakaran juga sangat penting untuk diketahui oleh nakhoda dan perwira kapal penangkapan ikan yaitu mulai dari peraturan mengenai perlengkapan pemadam kebakaran sampai dengan cara pengaplikasian dan perawatan alat-alat pemadam kebakaran (STCW-F 1995).

Pengetahuan tentang penyelamatan sangat penting karena apabila kapal mengalami kecelakaan seperti tubrukan, kebocoran, tenggelam dan sebagainya maka nakhoda dan perwira harus memiliki pengetahuan yang memadai tentang alat-alat penyelamatan dan pengaturannya serta pengetahuan menyeluruh tentang prosedur darurat (STCW-F 1995). Awak kapal perlu untuk melakukan latihanlatihan cara penolongan di atas kapal untuk meminimalisir kesalahan ketika berada di lapangan. Pengetahuan pencarian dan pertolongan harus dikuasai oleh awak kapal untuk kepentingan keselamatan jiwa di laut sebagaimana diamanatkan dalam amandemen konvensi internasional tentang pencarian dan pertolongan (SAR) maritim 1979 yang tercantum pada Peraturan Presiden Republik Indonesia nomor 30 tahun 2012.

Keselamatan kerja merupakan salah satu syarat minimal bekerja di kapal penangkap ikan dengan tujuan memastikan awak kapal perikanan tangkap memiliki kondisi layak di atas kapal penangkap ikan (ILO No. 88 2007). Keselamatan dalam berlayar penting untuk diterapkan oleh semua awak kapal penangkapan ikan karena faktor keselamatan adalah suatu penunjang keberhasilan aktivitas penangkapan di laut. Keselamatan dalam penangkapan ikan adalah salah satu yang menjadi perhatian dunia. Pelaut yang bekerja di atas kapal memiliki potensi kecelakaan kerja yang sangat tinggi, karena kecelakaan yang terjadi di laut pada umumnya disebabkan oleh pelaut itu sendiri, yaitu mereka kurang menguasai bidang pekerjaannya. Sekitar $42 \%$ kecelakaan yang terjadi disebabkan oleh human error karena keterampilan dan keahlian yang dimiliki awak kapal rendah, serta penyebab kecelakaan lainnya adalah tenggelam akibat stabilitas kurang baik, kerusakan kapal karena konstruksi kapal yang tidak tahan terhadap terjangan ombak dan kapal (FAO 2000). Selain kurikulum pengetahuan nakhoda di atas maka perlu diperhatikan sarana dan prasaran minimum yang harus ada pada lembaga pendidikan pengambilan sertifikat ANKAPIN-I.

Menurut PERMENKP No. 7 tahun 2011 tentang Sistem Standar Mutu Pendidikan dan Pelatihan paling sedikit yaitu ruang perkantoran, ruang kelas, laboratorium/workshop, sarana simulasi yang mendukung proses belajar mengajar, buku-buku referensi dan kapal latih. Jika suatu lembaga tidak memiliki sarana dan prasarana minimum ANKAPIN-I maka lembaga pendidikan tersebut bisa bekerja sama dengan lembaga lain yang telah terakreditasi.

Berdasarkan Tabel 2 implementasi kurikulum kompetensi STCW-F 1995 di lembaga pendidikan memiliki 16 kurikulum sehingga memiliki nilai sebesar 76,2\%. Persentase nilai implementasi diperoleh dari hasil perhitungan kesenjangan kurikulum lembaga pendidikan terhadap kurikulum STCW-F 1995. Persentase ketidaksesuaian kurikulum di lembaga pendidikan yaitu sebesar 23,8\%. Ketidaksesuaian tersebut disebabkan kurikulum di lembaga pendidikan tidak menerapkan semua kurikulum atau pengetahuan minimum yang berlaku. Jumlah materi yang terdapat di dalam konvensi STCW-F 1995 ada 21 materi sementara yang telah diterapkan/diakomodir oleh lembaga pendidikan hanya mencapai 20 materi. Hal ini menunjukkan bahwa kurikulum lembaga pendidikan belum sepenuhnya mengadopsi kurikulum yang ditetapkan pada konvensi STCW-F 1995. Selain itu, 20 materi tersebut juga hanya terdapat 16 materi yang telah diimplementasikan di lembaga pendidikan, sedangkan sisanya 4 materi adalah kurikulum yang mendalami prosedur penangkapan ikan di laut mulai dari kapal penangkap ikan sampai dengan penangkapan ikan yang bertanggung jawab. Menurut KKP, 2019 standar pengetahuan minimum untuk mendapatkan sertifikat harus mengadopsi seluruh isi materi Peraturan Presiden Nomor 18 Tahun 2019 tentang Ratifikasi STCW-F 1995. 


\section{Pencapaian Kurikulum ANKAPIN-I Terhadap Kurikulum STCW-F 1995}

STCW-F 1995 sudah mengatur pengetahuan dan syarat minimum menjadi seorang nakhoda dan perwira laut di atas kapal penangkap ikan. Menjadi nakhoda dan perwira kapal penangkap ikan yang kompeten harus menguasai semua pengetahuan minimum yang telah dicantumkan pada konvensi STCW-F1995, di mana lembaga pendidikan menerapkan kurikulum dan mengikuti prinsip-prinsip pendidikan sebagaimana diatur dalam konvensi STCW-F 1995. STCW-F 1995 merupakan titik acuan secara internasional yang dijadikan sebagai pedoman pengambilan sertifikasi tingkat ANKAPIN-I. Kurikulum dalam pengambilan sertifikasi ANKAPIN-I di Indonesia yang diterapkan di lembaga pendidikan masih memiliki elemen-elemen yang belum tercapai dengan elemen yang diatur dalam konvensi STCW-F 1995. Elemen menurut kamus bahasa Indonesia adalah bagian (yang penting, yang dibutuhkan) dari keseluruhan yang lebih besar.

Elemen yang belum ada dalam kurikulum yaitu perencanaan pelayaran di perairan yang terdapat es, penerapan peraturan internasional untuk mencegah tubrukan di laut, 1972, kebugaran awak kapal, tindakan kehati-hatian dalam olah gerak untuk peluncuran sekoci penolong atau rakit penolong dalam cuaca buruk, pengetahuan tentang tindakan-tindakan praktis untuk dilakukan ketika berlayar di perairan ber-es, gunung es atau terjadi penimbunan es di atas kapal dan olah gerak dalam pengisian bahan bakar di laut. Kondisi atau tingkat pencapaian (kesesuaian) elemen pada kurikulum ANKAPINI dibandingkan dengan elemen pada kurikulum STCW-F 1995 disajikan pada Gambar 1.

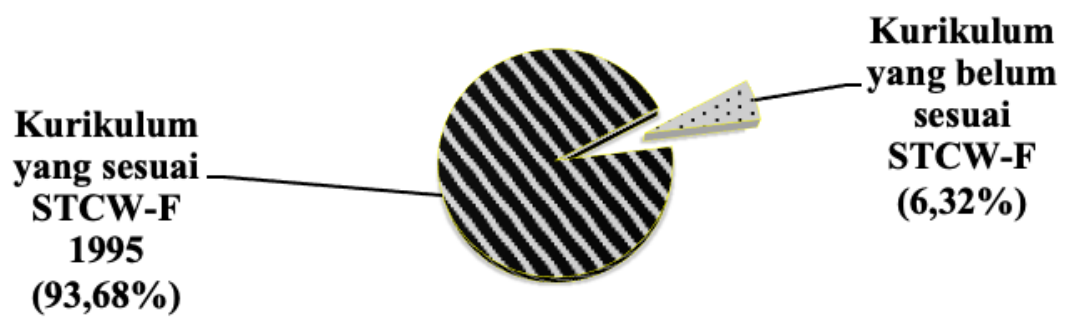

Gambar 1 Persentase implementasi elemen pada kurikulum ANKAPIN-I

Pada Gambar 1 terlihat bahwa jumlah elemen dari 16 materi kurikulum yang sudah diadopsi di lembaga pendidikan Indonesia yaitu sebanyak 89 dari 95 elemen dengan nilai persentase sebesar 93,68\%. Nilai persentase diperoleh dari hasil perhitungan kesesuaian kurikulum lembaga pendidikan terhadap kurikulum konvensi STCW-F 1995. Elemen yang belum diterapkan atau yang belum sesuai dengan harapan hanya 6 elemen (6,32\%). Hal ini menunjukkan bahwa tingkat kesesuaian kurikulum ANKAPIN-I terhadap kurikulum STCW-F 1995 termasuk kategori baik/memadai untuk meningkatkan pengetahuan, kecakapan dan pemahaman nakhoda dan perwira di atas kapal penangkap ikan. Meskipun demikian keenam elemen yang belum tercapai masih perlu disempurnakan lagi mencapai nilai 100\% dan kompetensi nakhoda serta perwira yang bekerja di atas kapal penangkap ikan lebih baik. Adapun keenam elemen dimaksud adalah perencanaan pelayaran di perairan yang terdapat es, penerapan peraturan internasional untuk mencegah tubrukan di laut 1972, memperhatikan kebugaran para $A B K$, tindakan kehati-hatian dalam olah gerak untuk peluncuran sekoci penolong atau rakit penolong dalam cuaca buruk, pengetahuan tentang tindakan-tindakan praktis untuk dilakukan ketika berlayar di perairan ber-es, gunung es atau terjadi penimbunan es di atas kapal dan olah gerak dalam pengisian bahan bakar di laut.

Perencanaan pelayaran yang terdapat es merupakan sangat penting untuk dipelajari oleh seorang pelaut pemegang sertifikat ANKAPIN-I atau bekerja di atas kapal ukuran $\geq 24$ meter. Pelaut Indonesia yang akan bekerja di atas kapal asing harus dibekali dengan pengetahuan perencanaan berlayar di laut yang terdapat es dan memiliki kemampuan untuk meminimalisir risiko bahaya. Pelaut 
lokal atau pelaut Indonesia harus memiliki kemampuan dalam melakukan pelayaran di kawasan yang terdapat es karena berlayar di kawasan laut negara asing ada yang memiliki perairan ber-es seperti negara bagian kutub contohnya Norwegia, Kanada, Swedia, Finlandia, Denmark, Islandia dan sebagainya. lembaga pendidikan perlu menambahkan materi tentang pelayaran di kawasan ber-es untuk meningkatkan kualitas nakhoda, perwira kapal maupun anak buah kapal.

Anak buah kapal merupakan semua crewatau pekerja di atas kapal kecuali nakhoda. Anak buah kapal adalah tanggung jawab oleh nakhoda selama melakukan pelayaran. Nakhoda wajib memperhatikan semua anggotanya mulai dari jam istirahat, operasi penangkapan atau aktivitas selama bekerja di atas kapal dan memperhatikan kebugaran atau kondisi tubuh seluruh awak kapal. Hal ini sangat penting untuk dilakukan oleh seorang nakhoda karena berpengaruh pada keselamatan kerja. Berjalannya suatu aktivitas di atas kapal dengan baik tergantung pada kinerja para ABK, jika anak buah kapal tidak nyaman atau mengalami stress maka kinerja ABK akan turun (Soeboer et al. 2018). Salah satu yang sangat mempengaruhi kinerja para awak kapal adalah kebugaran awak kapal, jika awak kapal dalam keadaan tidak bugar atau tidak sehat maka akan mempengaruhi aktivitas penangkapan ikan bahkan merugikan pihak perusahaan. lembaga pendidikan perlu mengajarkan pengetahuan kepada para calon nakhoda atau perwira kapal untuk bersikap baik dalam bersosialisasi dengan para crew kapal. Koordinasi dan kerjasama harus berjalan dengan baik dan lancar sesuai dengan prosedur. Selain itu, kebugaran atau kesehatan para ABK juga perlu diperhatikan agar mereka mampu menghadapi kondisi/suasana yang cukup berat di laut, seperti cuaca buruk. Koordinasi yang baik antara atasan dengan bawahan harus tercipta di atas kapal untuk mewujudkan kinerja yang bagus (Eko et al. 2018).

Kinerja para anak buah kapal sangat penting untuk memaksimalkan operasi penangkapan ikan. Anak Buah kapal yang memiliki kinerja yang bagus akan melancarkan operasi penangkapan ikan sehingga hasil tangkapan dapat meningkat. Hasil tangkapan yang meningkat akan menguntungkan perusahaan dan para anak buah kapal. Aktivitas di atas kapal sangat beragam mulai dari kerja yang berat sampai kerja yang ringan dan ada yang membutuhkan ketelitian dan kehati-hatian dalam melakukan tindakan. Salah satu yang harus diperhatikan adalah tindakan kehati-hatian dalam olah gerak untuk peluncuran sekoci penolong atau rakit penolong dalam cuaca buruk. Apabila kapal dalam situasi yang tidak diinginkan maka nakhoda harus bisa mengakomodir para ABK untuk melakukan tindakan yang tepat dalam menangani situasi tersebut seperti peluncuran sekoci penolong ketika kapal mengalami kecelakaan di laut. Peluncuran sekoci penolong memerlukan pengetahuan dan kemampuan ABK yang baik, seperti bagaimana cara menurunkan sekoci penolong, penempatan sekoci penolong dan sebagainya. Sekoci penolong harus ditempatkan sedemikian rupa sehingga mudah jika diturunkan dalam waktu yang singkat. Sekoci penolong tidak boleh dipasang pada bagian belakang kapal, apabila diturunkan dapat membahayakan karena dekat dengan propeller (Kemendikbud 2015).

Tindakan-tindakan lain yang harus dikuasai oleh anak buah kapal yaitu tindakan praktis jika berada di perairan ber-es, jika terjadi penumpukan es di atas kapal dan olah gerak kapal dalam pengisian bahan bakar. Anak buah kapal harus siap siaga dalam setiap kondisi apapun, karena jika terjadi kecelakaan anak buah kapal harus gerak cepat melakukan tindakan dalam menangani situasi bahaya. Peristiwa yang sering terjadi adalah olah gerak kapal atau stabilitas kapal yang labil/tidak konstan akibat adanya faktor luar maupun faktor dari dalam seperti cuaca, angin dan bentuk dari kapal itu sendiri (Eko et al. 2018). Menjaga stabilitas kapal sangat penting untuk mencegah kapal terbalik seperti pada saat melakukan setting dan hauling. Selain stabilitas kapal tindakan terhadap penanganan hasil tangkapan juga harus diperhatikan seperti pemberian es selama melakukan proses penanganan hasil tangkapan. ABK harus memiliki pengetahuan dalam menangani hasil tangkapan karena setelah ikan diangkat dari laut ke atas kapal, saat itu ABK harus segera menangani hasil tangkapan dengan waktu yang cepat agar kualitas ikan tetap terjaga. ABK harus menghitung penggunaan es batu dalam proses penyimpanan ikan agar tidak terjadi penumpukan es di atas kapal. Proses pendinginan ikan secara berlapis dimulai dari penangkapan sampai ke pasar pelelangan ikan. Proses pendinginan juga dapat dilakukan cara ikan bertumpuk yaitu dengan cara menempatkan ikan pada cool box kemudian diikuti dengan timbunan es 
batu yang sudah dicacah. Perbandingan antara es dengan ikan pada umumnya yaitu 1:1, di mana 1 kwintal ikan membutuhkan 1 balok es batu dengan berat 20-25 kg (Zulaihah et al. 2018). Es yang terlalu banyak menyebabkan kerusakan fisik pada ikan karena himpitan es dan sebaliknya jika es terlalu sedikit maka suhu ikan tidak dingin menyebabkan ikan tidak segar. Penanganan hasil tangkapan merupakan sangat penting dalam rantai industri perikanan, maka hasil tangkapan harus memiliki kualitas yang tinggi hingga sampai ke tangan konsumen. Penempatan atau penyusunan hasil tangkapan juga harus diperhatikan agar menjaga kapal tidak oleng.

Untuk menerapkan ke-enam elemen-elemen di atas selain mengadopsi materi yang terkait, dari segi sarana dan prasarana lembaga pendidikan Indonesia juga harus mendukung. Salah satu sarana prasarana yang dibutuhkan adalah buku-buku referensi dari negara maju yang terkait ke-enam elemen tersebut. Selain itu, awak kapal Indonesia harus banyak belajar kepada awak kapal negara lain yang telah mengadopsi konvensi STCW-F 1995 yaitu dengan cara yang pertama, pemerintah dapat mengikat sistem kerjasama kepada negara yang mengadopsi konvensi tersebut. Kedua, yaitu dengan mewadahi calon nakhoda atau perwira kapal penangkap ikan 24 meter atau lebih dengan magang di atas kapal penangkap ikan luar negeri. Pihak pemerintah juga perlu mengawasi dan memperhatikan kecakapan, keahlian dan keterampilan para calon nakhoda dan perwira kapal penangkap ikan 24 meter atau lebih untuk menciptakan kredibilitas lembaga pendidikan dalam pengambilan sertifikasi ANKAPIN-I. Pemerintah harus mendukung para calon awak kapal dari segi dana maupun perizinan.

Beberapa faktor yang menyebabkan adanya kesenjangan atau perbedaan kurikulum pengambilan sertifikat ANKAPIN-I di Indonesia dengan konvensi STCW-F 1995 yang pertama adalah rendahnya perhatian pemerintah terhadap pengawasan penerapan kebijakan yang mengatur kapal penangkap ikan sehingga banyak pelaut meremehkan tindakan-tindakan atau peraturan yang berlaku. Yang kedua adalah adanya anggapan bahwa kapal penangkap ikan di Indonesia yang berukuran 24 meter ke atas masih sedikit dan KKP lebih fokus kepada nelayan domestik yang didominasi kapal di bawah 24 meter, oleh karena itu standar mutu pendidikan pelaut yang bersertifikat ANKAPIN-I kurang diperhatikan oleh pemerintah. Indonesia mempunyai armada penangkapan ikan yang berukuran 24 meter tercatat sebanyak 330 unit kapal. Sementara itu, jumlah awak kapal di Indonesia sebanyak 2,6 juta orang diperkirakan 7.260 orang bekerja pada armada kapal berukuran panjang 24 meter atau lebih (KKP 2015). Hal ini menunjukkan bahwa ABK dan jumlah kapal penangkap ikan berukuran 24 meter ke atas tergolong banyak. Berdasarkan data jumlah awak kapal penangkap ikan Indonesia masih tergolong dalam kategori yang belum memiliki kompetensi yang memadai. Berdasarkan data jumlah armada kapal penangkap ikan sebaiknya pemerintah mengatur dan menerapkan semua sistem pendidikan yang sudah sesuai dengan konvensi STCW-F 1995 atau Peraturan Presiden Nomor 18 Tahun 2019 tentang Ratifikasi STCW-F 1995 guna menjadi salah satu instrumen yang dapat menjamin terlindungnya hak-hak dasar bagi awak kapal Indonesia terutama yang bekerja di luar negeri.

\section{KESIMPULAN DAN SARAN}

Kurikulum ANKAPIN-I di lembaga pendidikan Indonesia belum sesuai dengan Peraturan Presiden Nomor 18 Tahun 2019 tentang Ratifikasi STCW-F 1995. Namun kesesuaian kurikulum atau yang sudah diadopsi di Lembaga Pendidikan Indonesia cukup baik yaitu 76,2\%. Ketidaksesuaian kurikulum dalam pengambilan sertifikasi ANKAPIN-I di Lembaga Pendidikan memiliki nilai sebesar 23,8\%. Ketidaksesuaian kurikulum atau yang belum diadopsi tersebut yaitu tata laksana keselamatan FAO/ILO/IMO untuk awak kapal penangkap ikan 24 meter ke atas, pencegahan kebakaran dan alatalat pemadam kebakaran, penyelamatan, pencarian dan pertolongan serta pelayanan medis.

Materi atau elemen yang ada pada Kurikulum lembaga pendidikan Indonesia belum sesuai dengan materi atau elemen yang terdapat pada Peraturan Presiden Nomor 18 Tahun 2019 tentang Ratifikasi STCW-F 1995. Materi yang sudah sesuai yaitu sebesar 93,68\% dan yang belum sesuai sebesar 6,32\%. Elemen atau materi pengetahuan dasar yang masih kurang berdasarkan standar STCW-F 1995 
yaitu perencanaan pelayaran di perairan yang terdapat es, penerapan peraturan internasional untuk mencegah tubrukan di laut 1972, memperhatikan kebugaran para ABK, tindakan kehati-hatian dalam olah gerak untuk peluncuran sekoci penolong atau rakit penolong dalam cuaca buruk. Serta pengetahuan tentang tindakan-tindakan praktis untuk dilakukan ketika berlayar di perairan ber-es, gunung es atau terjadi penimbunan es di atas kapal dan olah gerak dalam pengisian bahan bakar di laut, penyelamatan dan pemadam kebakaran.

\section{UCAPAN TERIMA KASIH}

Penghargaan penulis sampaikan kepada Dr. Ita Junita Puspa Dewi, A.Pi., M.Si dari Sekolah Tinggi Perikanan Jakarta yang telah memberikan izin kepada penulis untuk melakukan penelitian di Sekolah Tinggi Perikanan Jakarta.

\section{DAFTAR PUSTAKA}

Adela NF. 2018. Perlindungan pelaut Indonesia di Luar Negeri melalui ratifikasi maritime labour convention 2006. Jurist-Diction. 1(2): 658-660.

Arleiny \& Prastyanti RA. 2019. Optimalisasi fitness for duty pelaut berdasarkan peraturan menteri kesehatan republik Indonesia nomor 1 tahun 2018 tentang pemeriksaan kesehatan pelaut. Jurnal Ilmiah Rekam Medis Dan Informatika Kesehatan. 9(1): 51-52.

Arsham M, Jakub M, Jari N, Pentti K. 2015. Usability of accident and incident reports for evidencebased risk modeling - A case study on ship grounding reports. Safety Science. 76: 202-214.

Aji MMK. 2017. Hukum mahar dalam tajdidun nikah [skripsi]. Semarang: Universitas Islam Negeri Walisongo.

Budiman MS, Iskandar BH \& Seboer DA. 2016. Penataan sertifikasi kompetensi awak kapal penangkap ikan di indonesia. Jurnal Teknologi Perikanan Dan Kelautan. 7(2): 146-152.

Eko M, Subardi A \& Suryadana MI. 2018. Faktor penghambat pelaksanaan olah gerak beaching di Kapal LCT Adinda Diza. Jurnal Dinamika Bahari. 8(2): 2077-2090.

Food and Agriculture Organization. 2000. The State of World Fisheries and Aquaculture.

Indonesia, Jakarta. Hasugian S, Wahyuni A, Rahmawati M \& Arleiny. 2017. Pemetaan karakteristik kecelakaan kapal di perairan Indonesia berdasarkan investigasi KNKT. 29(2): 230-231.

HM Thamrin Ar.2015. Manajemen keselamatan maritim dan upaya pencegahan kecelakaan kapal ke titik nol (Zero Accident). 3(2): 111-112.

[KKP] Kementerian Kelautan dan Perikanan Republik Indonesia. 2015. Rancangan Peraturan Presiden Republik Indonesia Konvensi Internasional Tentang Standar Pelatihan, Sertifikasi Dan Tugas Jaga Bagi Awak Kapal Penangkap Ikan, 1995.

[KKP] Kementerian Kelautan dan Perikanan Republik Indonesia. 2011. Peraturan Menteri Kelautan dan Perikanan No. 7 tentang Sistem Standar Mutu Pendidikan dan Pelatihan, Ujian dan Sertifikasi Pelaut Kapal Penangkap Ikan.

[KemenDikBud] Kementerian Pendidikan dan Kebudayaan Republik Indonesia. 2015. Dasar-dasar Keselamatan di Laut 1.

[KemenHub] Kementerian Perhubungan Republik Indonesia. 2013. Peraturan Menteri Perhubungan No. 84 tentang Perekrutan dan Penempatan Awak Kapal. 
[KemenHub] Peraturan Menteri Perhubungan RI. 2005. Peraturan Menteri Perhubungan RI No.9 tentang Pendidikan dan Pelatihan, Ujian Serta Sertifikasi Pelaut Kapal Penangkapan Ikan.

[KemenHub] Peraturan Menteri Perhubungan. 2013. Peraturan Menteri Perhubungan No. 70 tentang Pendidikan dan Pelatihan Sertifikasi serta Dinas Jaga Pelaut.

Kepala BPSDMP. 2016. Kepala badan pengembangan SDM Perhubungan No.07 tentang Kurikulum program pendidikan dan pelatihan pembentukan dan peningkatan kompetensi di bidang pelayaran.

Mahsun. 2007. Metode Penelitian Bahasa. PT Raja Grafindo Persada. Jakarta.

Manoppo RM. 2013. Analisis system pengendalian intern penerimaan dan pengeluaran kas pada pt. sinar galesong prima cabang Manado. Jurnal EMBA. 1(4): 1007-1015.

Neuendorf KA. 2002. The Content Analisys Guidebook. Sage Publications Inc.

Oktaviani RW \& Suryana RN. 2006. Analisis kepuasan pengunjung dan pengembangan fasilitas wisata agro (studi kasus di kebun wisata pasir mukti, Bogor). Jurnal Agro Ekonomi. 24(1): 44-45.

[PermenPerhub] Peraturan Menteri Perhubungan. 2008. No. 30 tentang dokumen identitas pelaut.

[PP] Peraturan Presiden Republik Indonesia. 2012. No. 30 tentang Pencarian dan Pertolongan Maritim, 1979.

[PP] Peraturan Presiden Republik Indonesia. 2019. No. 18 tentang Ratifikasi STCW-F 1995.

Prayogo D. 2020. Pelatihan Basic Safety Training (BST) kepada nelayan tegal untuk menunjang keselamatan pelayaran. Jurnal Pengabdian Kepada Masyarakat. 11(2): 236-239.

Rini S, Aswati S, Honny F. 2018. Kepemimpinan di atas kapal leadership on a ship. Jurnal Manajemen Transportasi dan Logistik. 5(3): 238-239.

Samudra RG. 2020. ABK (nelayan) di dalam Kapal Cina [Internet]. Bogor (ID): Dramaga. Hlm 1-9; [diunduh $2021 \quad$ Feb 11$]$ Tersedia pada: file://C:/Users/user/Downloads/Syarat\%20UAS\%20Kewarganegaraan\%20(2).pdf

Sevilla, Consuelo G. 1993. Pengantar Metode Penelitian. Jakarta : UI Press.

Setiawati, W., Oktavia Asmira, Yoki Ariyana, Reisky Bestary, Ari Pudjiastuti. 2019. Buku Penilaian Berorientasi Higher Order Thinking Skills. Jakarta: Direktorat Jendral Guru dan Tenaga Kependidikan Kementrian Pendidikan dan Kebudayaan.

Soeboer DA, Imron M, Iskandar BH dan Laksono MP. 2018. Aspek Ergonomi Pada Aktivitas Penangkapan Ikan Dengan Kapal Payang di Pelabuhanratu-Sukabumi. Albacore. 2(3): 343-344.

Sugiyono. 2012. Metode Penelitian Kuantitatif Kualitatif dan R\&D. Alfabeta. Bandung (ID).

[UU] Undang-Undang Republik Indonesia Nomor 17 Tahun 2008 tentang Pelayaran.

[UU] Undang-Undang Republik Indonesia Nomor 24 Tahun 2000 tentang Perjanjian Internasional.

Zulaihah L. Nur I \& Marasabessy A. 2018. Program pendinginan ikan pada kelompok pedagang pasar pelelangan Muara Baru Jakarta Utara. Prosiding Seminar Nasional Penelitian dan Pengabdian pada Masyarakat (hal 1-4). 